\title{
Knowledge about precautions in Primary Health Care: tool validation
}

\author{
Conhecimento sobre precauções na Atenção Primária à Saúde: validação de instrumento
}

Conocimiento sobre precauciones en la Atención Primaria a la Salud: validación de instrumento

\section{Michelli Pacheco Sako', Adriana Maria da Silva Felix", Julia Yaeko Kawagoe ${ }^{\mathrm{III}}$, Maria Clara Padoveze ${ }^{\mathrm{IV}}$, Silvia Alice Ferreirav, Silvia Helena Zem-Mascarenhas', Stephen Timmons ${ }^{\mathrm{vI}}$, Isis Pienta Batista Dias Passos', Rosely Moralez de Figueiredo' \\ ' Universidade Federal de São Carlos. São Carlos, São Paulo, Brazil. \\ "Santa Casa de São Paulo, Faculty of Medical Sciences. São Paulo, Brazil \\ II' Albert Einstein Israelita, Faculty of Health Sciences. São Paulo, Brazil. \\ IV Universidade de São Paulo, Nursing School. São Paulo, Brazil. \\ $\checkmark$ Estado de São Paulo, Health Department. São Paulo, Brazil. \\ ${ }^{v \prime}$ The University of Nottingham. Nottingham, United Kingdom of Great Britain and Northern Ireland.}

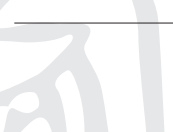

How to cite this article:

Sako MP, Felix AMS, Kawagoe JY, Padoveze MC, Ferreira SA, Zem-Mascarenhas SH, et al. Knowledge about precautions in Primary Health Care: tool validation. Rev Bras Enferm [Internet]. 2018;71(Suppl 4):1589-95.

[Thematic Issue: Education and teaching in Nursing] DOI: http://dx.doi.org/10.1590/0034-7167-2017-0886

\section{Submission: 11-28-2017 Approval: 01-24-2018}

\begin{abstract}
Objective To elaborate and validate a tool to assess knowledge and behavior of nursing professionals about standards and specific precautions in the Primary Health Care. Method: Methodological study of the elaboration and validation of the tool by thirteen experts judges, using a Likert scale of 4 points, with Content Validity Index $\geq 0.80$, on clarity, relevance and pertinence. Results: A tool composed of 47 dichotomous questions to assess knowledge and 12 questions, with five options of answers, for the referred behavior. In the validation, only one item was deleted, related to the "Hands Hygiene" axis and one item was reformulated, regarding "Use of Common Gloves" and another 11 changed writing. The tool as a whole was assessed for relevance, comprehensiveness and representativeness within the scope of the topic investigated. Conclusion: The developed tool has been validated and is now available for use in Primary Health Care.
\end{abstract}

Descriptors: Primary Health Care; Universal Precautions; Validation Studies; Nursing; Continuing Education in Nursing.

\section{RESUMO}

Objetivo: Elaborar e validar instrumento para avaliação do conhecimento e comportamento referido dos profissionais de enfermagem sobre precauções padrão e específica na Atenção Primária à Saúde. Método: Estudo metodológico de elaboração e validação do instrumento, por treze juízes especialistas, por meio de escala tipo Likert de 4 pontos, com Índice de Validade de Conteúdo $\geq 0$,80, sobre clareza, relevância e pertinência. Resultados: Instrumento composto por 47 perguntas dicotômicas para avaliar o conhecimento e 12 perguntas, com cinco opções de respostas, para o comportamento referido. Na validação, apenas um item foi excluído, relativo ao eixo "Higiene das mãos" e um item foi reformulado, relativo a "Uso de luvas" e outros 11 passaram por alteração de redação. Foi avaliado o conjunto do instrumento quanto à relevância, abrangência e representatividade dentro do escopo do tema investigado. Conclusão: A ferramenta desenvolvida foi validada e está agora disponível para uso na Atenção Primária à Saúde.

Descritores: Atenção Primária à Saúde; Precauções Universais; Estudos de Validação; Enfermagem; Educação Continuada em Enfermagem.

\section{RESUMEN}

Objetivo: Elaborar y validar instrumento para evaluación del conocimiento y comportamiento referido de los profesionales de enfermería sobre precauciones estándar y específica en la Atención Primaria a la Salud. Método: Estudio metodológico de elaboración y validación del instrumento, por trece jueces especialistas, por medio de escala tipo Likert de 4 puntos, con Índice de Validez de Contenido $\geq 0,80$, sobre claridad, relevancia y pertinencia. Resultados: Instrumento compuesto por 47 preguntas dicotómicas para evaluar el conocimiento y 12 preguntas, con cinco opciones de respuestas, para el comportamiento referido. En la validación, sólo un ítem fue excluido, relativo 
al eje "Higiene de las manos" y un ítem fue reformulado, relativo a "Uso de guantes" y otros 11 pasaron por alteración de redacción. Se evaluó el conjunto del instrumento en cuanto a la relevancia, alcance y representatividad dentro del alcance del tema investigado. Conclusión: La herramienta desarrollada ha sido validada y está ahora disponible para su uso en la Atención Primaria a la Salud. Descriptores: Atención Primaria a la Salud; Precauciones Universales; Estudios de Validación; Enfermería; Educación Continua en Enfermería.

\section{CORRESPNDING AUTHOR Rosely Moralez de FigueiredoＥ-mail: rosely@ufscar.br}

\section{INTRODUCTION}

Improved patient safety and health service quality with focus on reducing Healthcare Associated Infections (HCAI) have received special attention since they are considered a major public health challenge in Brazil and globally ${ }^{(1-2)}$.

Among the ways of prevention of HCAl enshrined worldwide, is the adoption of measures known as Standard Precautions (StanP) and Specific Precautions (SpeP) ${ }^{(3-4)}$, which aim to reduce the risk of transmission of microorganisms to patients and professionals. StanP is a measure that should be used with all patients regardless of the occurrence of a suspected or confirmed diagnosis, and includes Hands Hygiene $(\mathrm{HH})$, use of Personal Protective Equipment (PPE), respiratory label, physical area care, environment and waste management ${ }^{(5-7)}$. SpeP is an additional measure that should be used when StanP is not enough to stop the transmission of pathogens through contact, droplet or aerosol. In Primary Health Care (PHC), the most common situations requiring SpeP are: pulmonary or laryngeal tuberculosis and varicella (aerosols), influenza (droplets), scabies and multiple drug resistant microorganisms (contact) ${ }^{(5)}$.

It is well known that adherence to such measures is still a challenge among health professionals ${ }^{(8-9)}$. This study points out that some professionals do not agree or disregard the recommendations of preventive measures besides not recognizing the moment in which they must carry out them ${ }^{(10)}$. In another study, the authors found that the professionals studied, when questioned, reported adherence to $\mathrm{HH}$ but in the systematic observation of the practice, this was not confirmed ${ }^{(11)}$.

These studies ${ }^{(9-11)}$ were mostly performed in the hospital setting. In PHC, however, this risk of HCAI is unknown, which is considered concerning, since it is one of the great entry points of the health system in the country, in addition to the diversity of actions that take place there. Performing invasive procedures, such as administration of medication, vaccination and dressings, is part of the PHC routine; the control and search of patients with infectious diseases such as tuberculosis; in addition to the first outbreak care, such as influenza A, for example ${ }^{(5)}$. Another situation that is increasingly frequent and still little investigated, but observed empirically, is the transfer of care from patients who are discharged from hospital with multiple drug resistant microorganisms and continue their care in PHC.

The present study was based on a previous study carried out with PHC professionals, where low perception of infection risk was identified, lack of specific training in the subject, infrastructure limitations and knowledge gaps, particularly on $\mathrm{HH}$, tuberculosis and manipulation of sharps at home ${ }^{(12)}$. The achievement of this is also justified by the relevance of HCAl transmission in $\mathrm{PHC}$, the rare epidemiological reports on this population $^{(5)}$, the acknowledged deficit of adherence to StanP and SpeP by health professionals in general ${ }^{(11)}$, the difficulty of comparison between the results of the few recent studies in this care setting ${ }^{(12-16)}$ and the limited availability of assessment tools ${ }^{(17-18)}$, which have not yet been validated.

\section{OBJECTIVE}

To elaborate and validate a tool for the assessment of knowledge and behavior reported by the nursing professionals on StanP and SpeP in PHC.

\section{METHOD}

\section{Ethical aspects}

The project was approved by the Research Ethics Committee of the Universidade Federal de São Carlos - UFSCar, according to Ordinance 466/12 of the National Health Council (Conselho Nacional de Saúde- CNS) and the participants signed the Informed Consent Form.

\section{Design, place of study and period}

This is a quantitative and methodological development study that describes the steps for the elaboration and validation of a tool to assess knowledge and behavior reported by nursing professionals on StanP and SpeP in PHC.

The results of the methodological research can support the theoretical formulation for the elaboration of an assessment methodology, being a facilitator when approaching the empirical data to the practice with the attainment of greater concreteness ${ }^{(19)}$. The study was carried out in a municipality in São Paulo State's countryside, from July 2015 to May 2016.

\section{Population and criteria for inclusion and exclusion}

The selection of judges occurred intentionally and not probabilistically. Twenty-seven nurses who met one of the following inclusion criteria were invited: minimum two-year professional experience in $\mathrm{PHC}$ care; minimum professional experience of two years and/or specialization in infection control; be a researcher in the Nursing area at PHC or in infection control. Thirteen nurses, from São Paulo State participated in the study, of which 11 were women, with a mean age of 35.1 years; average professional training time of 11.8 and average of 11 years. All of them had graduation degrees, of which six (46.1\%) had a master's degree, six (46.1\%) had a doctorate and one $(7.7 \%)$ had specialization in research-related areas. The tool for content validation was sent to the 13 judges, followed by a letter clarifying the research objectives and the Informed Consent Form. 


\section{Study protocol}

\section{Establishment of the conceptual framework}

The development of the tool was based on a previous study ${ }^{(12)}$, where knowledge gaps and interference or contribution factors were identified with adherence to the StanP, through focus groups with $\mathrm{PHC}$ health professionals.

The use of the experience of the target population, such as that obtained through the focal group, is recognized in the literature as an important source of material for the development of tools ${ }^{(20)}$.

In possession of this material, the concepts that would be addressed (operational definitions of the construct) were defined, in order to meet the objective of the tool. Already for its theoretical support, the following references were used:

- Guide to infection prevention in outpatient settings: minimum expectations for safe care $^{(3)}$. This is a synthesized guide of recommendations for infection prevention in an out-of-hospital environment. In general, the material reaffirms the adoption of StanP as a foundation for the prevention of transmission of infectious agents during patient care in all health care settings, and that the adoption of these measures represents the minimum expectations of infection prevention for safe ambulatory care.

- Hands hygiene in extra-hospital and home healthcare and in long-term care institutions ${ }^{(21)}$. It is known that best practices and strategies to improve hands hygiene are golden rules for global health. However, there are still few studies that assess the risk of microorganism transmission and the impact of implementing hands hygiene concepts in these locations. With these issues in mind, a World Health Organization (WHO) team from the "Clean Assistance is Safer Care" initiative organized the manual addressing the following key issues: 1) risk of transmission of microorganisms and infection, especially by hands, in out-of-hospital care settings; 2) practices of hands hygiene in these places; 3) adaptation of the patient's environment and the "My 5 moments for hands hygiene" approach and 4) implementation of improvement strategies at institutional level.

\section{Tool elaboration}

The construction of each item of a questionnaire should be carefully monitored to ensure clarity, objectivity, simplicity, accuracy, relevance and absence of deviations ${ }^{(19-20)}$. For that, the grouping of themes established in the conceptual structuring was followed, so that the tool contemplated all the topics listed.

The final tool developed, therefore, is composed of two modules, and Module A, through hit rates of the questions on precautions, aims to assess knowledge of the professional on the subject. This module is composed of five axes, one for each priority theme, in a total of 48 dichotomous questions with two choices, right or wrong. On the other hand, Module B aims to assess the frequency of good practice behavior on standard and specific precautions in everyday work situations. This module contains 12 Likert five-point scale questions, the answer options being: 5- Always; 4- Very Frequent; 3 - I Do Not Remember; 2- A Few Times; 1- Never.

An Operation Manual was also developed to guide the user about the use of the tool, containing the correct alternative, as well as a theoretical rationale introducing the subject and justifying the correct answer, in order to facilitate the understanding and use of the material.
Next, the tool was thoroughly discussed by peers in a research group meeting, for further referral to the experts judges for validation.

Only for the assessment of the judges was added the module C, composed of a dichotomous question that assessed the adequacy of the language to the intended audience, and six dichotomous questions, which objectified the relevance, comprehensiveness and representativeness of the questionnaire in general.

Regarding the assessment of the index of responses, it is considered that the ideal is $100 \%$ correct. Different scores of this indicate how much the professional's knowledge distances from the expected.

\section{Tool validation}

According to the literature ${ }^{(19-20)}$, the content validation stage must be carried out by a group of at least five to ten experts judges in the area of the measuring tool.

In this study, 13 judges participated in the content validation stage selected considering the experience and the high degree of knowledge of the same on the subject. The identification of these judges occurred by indication, snowball type, where contacted researchers indicated others renowned in the theme. The initial contact was by electronic mail where the objective of the work and the criteria for its appointment as judge were presented. If they agreed to participate, the Free and Informed Consent Form, along with the procedure and specific guidelines for validation, were also sent electronically.

All the judges were nurses, living in São Paulo State, 11 of them were women; mean age was 35.1 years; average professional training time of 11.8 and median of 11 years (minimum of 3 and maximum of 28 years). All of the participants have graduation degrees, six $(46.1 \%)$ with a master's degree, six $(46.1 \%)$ with a doctorate and one $(7.7 \%)$ with specialization in the research-related areas, in other words, $\mathrm{PHC}$, infection control or infectious diseases.

We have performed (face) apparent and content validations to guarantee the psychometric properties of each item of the tool.

The apparent validation assesss the relevance and adequacy of language, especially according to the target audience of application of the tool. Content validity, however, consists of evaluating whether the tool covers the entire content domain and the extent to which the issues are related to the subject. It is based on a judgment and often the use of a group of independent experts is often evidenced to assess the validity of new tools ${ }^{(19)}$.

The judges used a 4-point Likert scale, being: I strongly agree (4); I agree partially (3); I disagree partially (2) and I totally disagree (1), assesses each item of the tool for clarity, relevance and pertinence, in addition to the possibility of suggestions for redrafting. For the overall assessment of the material, the items relevance, clarity and representativeness of the tool set were assessed by dichotomous questions with two options of response yes (2) or no (1). The Content Validity Index (CVI) considered was 0.80 , in order to obtain a consensus level of $80 \%$, an index recommended by a review study available in the literature ${ }^{(20)}$.

\section{Analysis of results and statistics}

The answers were entered in a Microsoft Excel ${ }^{\circledR}$ System worksheet and for the validation of the components, in Modules A 
and B, options (3) and (4) were added as favorable, and options (1) and (2) as necessary reformulation or exclusion; in Module C options 2 were grouped for favorable and 1 for reformulation or deletion of the component. In all modules, for the component to be considered validated, it should reach the CVI greater than or equal to 0.80 for the favorable option.

\section{RESULTS}

Module A of the tool developed - Assessment of the hit rates for standard and specific precautions - includes five axes, namely A1. Identification of risks; A2. Hands hygiene; A3. Use of common gloves; A4. Use of mask and cough etiquette and A5. Safe medication and sharps disposal, to assess the professional's knowledge on the subject, in a total of 48 dichotomous questions.

In the validation of Module A, only two questions, in the Hands Hygiene and Glove Use axes, obtained CVI <0.80, both with CVI of 0.77 in the Clarity and Relevance aspects. After evaluating the comments issued by the judges, we opted for the exclusion of A2.4, considering that this could generate conceptual misunderstandings and the reformulation of A3.11 leaving the sentence more objective (Chart 1).

Chart 1 - Components of the tool excluded or reformulated post-validation by CVI (Content Validity Index)* $<0.80$, São Carlos, São Paulo State, Brazil, 2017

\begin{tabular}{|c|l|c|}
\hline Tool item & \multicolumn{1}{|c|}{ Content of the issue } & Conduct \\
\hline A2.4 & $\begin{array}{l}\text { In case of contact of the health } \\
\text { professional with objects or } \\
\text { surfaces used by the user, } \\
\text { hands hygiene should only be } \\
\text { performed after this contact, in } \\
\text { order to prevent the transmission } \\
\text { of microorganisms to other } \\
\text { people. Answer: Incorrect. }\end{array}$ & Excluded \\
\hline A3.11 & $\begin{array}{l}\text { To carry out simple dressing } \\
\text { the use of latex gloves is } \\
\text { indispensable, independent } \\
\text { of the use or not of clamps. } \\
\text { Answer: Incorrect. (Already with } \\
\text { the new essay) }\end{array}$ & Reformulated \\
\hline
\end{tabular}

Still in Module A, 11 other items, in spite of having obtained $\mathrm{CVI}>0.80$, received suggestions of changes of writing, in order to give greater clarity to them, and these were accepted. The final module was composed of 47 items, distributed in the five axes, according to Chart 2.

Module B - Assessment of the frequency of good practices in behavior regarding standard and specific precautions, in turn, is composed of 12 questions with five Likert type response options, ranging from "never" to "always". All of these questions, which assess the behavior of the professional when faced with daily work situations, obtained CVI $>0.80$ and were therefore validated. There was only suggestion of inversion in the order of writing of only one item (B1.2).
Chart 2 - Final composition of Module A of the tool regarding validated and adapted items, São Carlos, São Paulo State, Brazil, 2017

\begin{tabular}{|c|c|c|c|}
\hline Axes & $\begin{array}{l}\text { Number of } \\
\text { proposed } \\
\text { items }\end{array}$ & $\begin{array}{l}\text { Number of } \\
\text { validated } \\
\text { items }\end{array}$ & $\begin{array}{l}\text { Items that } \\
\text { have been } \\
\text { adapted in } \\
\text { the essay }\end{array}$ \\
\hline $\begin{array}{c}\text { A1. Risk } \\
\text { identification. }\end{array}$ & 6 & 6 & $2(\mathrm{~A} 1.2, \mathrm{~A} 1.6)$ \\
\hline $\begin{array}{l}\text { A2. Hands } \\
\text { hygiene. }\end{array}$ & 15 & 14 & $\begin{array}{l}4 \text { (A2.6, A2.7, } \\
\text { A2.8 e A2.9) }\end{array}$ \\
\hline $\begin{array}{l}\text { A3. Use of gloves } \\
\text { for procedures. }\end{array}$ & 11 & 11 & $\begin{array}{c}3 \text { (A3.5, A3.9, } \\
\text { A3.11) }\end{array}$ \\
\hline $\begin{array}{c}\text { A4. Use of } \\
\text { masks and cough } \\
\text { etiquettes. }\end{array}$ & 11 & 11 & -- \\
\hline $\begin{array}{l}\text { A5. Safe } \\
\text { Medication and } \\
\text { sharps disposal. }\end{array}$ & 5 & 5 & 2 (A5.1, A5.5) \\
\hline
\end{tabular}

In the overall assessment, the whole of the tool and its axes, Module C, were considered adequate for clarity, pertinence and representation within the theme by $100 \%$ of the judges and therefore considered valid (Chart 3).

Chart 3 - Overall assessment of the questionnaire, regarding relevance, comprehensiveness and representativeness, according to the opinion of judges, São Carlos, São Paulo State, Brazil, 2017

\begin{tabular}{|c|c|c|c|}
\hline & $\begin{array}{c}\text { Relevance } \\
(\text { CVI*) }\end{array}$ & $\begin{array}{c}\text { Comprehen- } \\
\text { siveness } \\
\text { (CVI*) }\end{array}$ & $\begin{array}{c}\text { Representa- } \\
\text { tiveness (CVI*) }\end{array}$ \\
\hline $\begin{array}{c}1-\text { The tool as } \\
\text { a whole. }\end{array}$ & 1.0 & 1.0 & 1.0 \\
\hline $\begin{array}{c}2-\text { Axis Risk } \\
\text { identification. }\end{array}$ & 1.0 & 0.8 & 1.0 \\
\hline $\begin{array}{c}3-\text { Axis Hands } \\
\text { hygiene. }\end{array}$ & 1.0 & 1.0 & 1.0 \\
\hline $\begin{array}{c}4-\text { Axis Use of } \\
\text { common gloves. }\end{array}$ & 1.0 & 0.9 & 0.9 \\
\hline $\begin{array}{c}5-\text { Axis Use } \\
\text { of masks and } \\
\text { cough etiquette. }\end{array}$ & 0.9 & 0.9 & 0.9 \\
\hline $\begin{array}{c}6-\text { Axis Safe } \\
\text { medication and } \\
\text { sharps disposal. }\end{array}$ & 0.9 & & \\
\hline
\end{tabular}

Note: ${ }^{*} \mathrm{CVI}$ Content Validity Index.

After the validation and final writing of the tool, the Operational Manual was elaborated, which discusses the essence of 
each axis, presents the template of the items and the reference used for the theoretical basis of the question. The tool and the instructions for its application contained in the Operation Manual are available from the authors of the study.

\section{DISCUSSION}

The elaborated tool aggregates the points identified as critical by the professionals participating in the $\mathrm{PHC}$ focus groups, in a step prior to this study, conferring an identity with the reality experienced by these, empowering the questionnaire.

It is believed that the origin of the content, coupled with the exhaustive discussion in the research group, until reaching the version sent to the judges, may have contributed to the high acceptance rate of the tool in the validation process. Recalling that in the tool as a whole there was only one item in the Hands hygiene axis (A2.4) and minor essay changes in another twelve.

The use of more than one parameter for assessment, that is, the degree of knowledge and the behavior referred to extends the scope of the tool, since it is a subject of great complexity and requires numerous approaches.

This study shows that despite the high level of knowledge and training on the subject, found in the study population, the mentioned behavior indicated that professionals recognize failures to adhere to precautions ${ }^{(22)}$.

It is known that knowledge on the subject is the basis for the adhesion process, but it is considered that other factors, such as social influence, attitudes, intentionality, institutional barriers can affect this practice ${ }^{(23)}$.

The final tool, after validation, has two modules, the $\mathrm{A}$ and the B. The module A, with 47 dichotomous questions divided into five axes, assesses the knowledge of the professional on the subject; the B, with 12 Likert five-point questions assesses the reported frequency of good practice behavior on standard and specific precautions in everyday work situations. In addition to the tool, there is also an Operation Manual in order to guide the user about the tool.

In module A, only two questions obtained CVI $<0.80$, in the axes "Hands hygiene" and "Use of gloves", one being excluded and the other reformulated.

It is known that $\mathrm{HH}$ is essential for reducing the risk of transmitting microorganisms in both the hospital and outpatient settings. Approximately $30 \%$ of HCAls may be preventable by basic measures such as $\mathrm{HH}^{(3,21)}$. However, in view of the available national and international literature on $\mathrm{HH}$, low compliance with established practices is evident, jeopardizing both user and professional safety ${ }^{(8,11)}$. In the extra-hospital environment, these data are still incipient ${ }^{(13-18)}$.

A Spanish study, carried out at PHC and in a hospital environment, found gaps in the knowledge of health professionals regarding the concept of hands hygiene and the use of alcohol solution ${ }^{(16)}$. In a Brazilian study, a low $\mathrm{HH}$ index was identified in PHC before procedures such as colpocytological and curative exams, with $16.6 \%$ and $50 \%$, respectively; and $50 \%$ in both ${ }^{(15)}$, which corroborates with those found in other studies, where the time of greatest adhesion to $\mathrm{HH}$ is after the procedure ${ }^{(24-25)}$.
The lack of adherence to HH's worldwide practice has been registered in other countries, such as Spain, where studies are also rare in the $\mathrm{PHC}$, but it is known that the $\mathrm{HH}$ adherence rate in the hospital environment varies between 30 and $50 \%$. A study carried out at the PHC in Madrid, where adherence to $\mathrm{HH}$ was observed at the five points indicated by the World Health Organization $(\mathrm{WHO})$, resulted in a value of $8.1 \%$ of adherence ${ }^{(13)}$.

In Nigeria, a study showed that nurses demonstrated good knowledge regarding infection control, but did not reflect on the level of adherence to practices ${ }^{(26)}$.

It is clear that greater attention should be directed to measures that corroborate to improve adherence to $\mathrm{HH}$, including PHC. The identification of gaps in knowledge and behavior, through this tool, can more accurately indicate themes for future educational interventions.

Regarding the use of gloves, the use of these gloves is recommended by the $\mathrm{WHO}$ as a barrier in reducing the risk of infection and should be used during all user assistance in which exposure to blood, other body fluids, contact with mucous membranes or skin not intact and to outbreak situations. In several clinical studies, the efficacy of gloves has been demonstrated to reduce the risk of contamination of the hands of health professionals and transmission of pathogens ${ }^{(3)}$.

This theme was used as the axis for this study due to the presence of failures in adherence to this precautionary measure, or its misuse already described in the literature ${ }^{(27)}$.

The use of latex gloves by health professionals during the care visits was observed in $66.3 \%$ of the situations in which they should have been used, being more evident in the Capillary Blood Glucose Test, where it was used only in $14 \%$ of the opportunities ${ }^{(25)}$. In dressings, it was used $100 \%$ of the time, but in $66.7 \%$ they were not used in conjunction with tools and after dressing were kept for other care in the user. In a hospital setting, another study identified the inadequate use of gloves, either by their unnecessary use or by using the same glove in different places of the same patient or in different patients ${ }^{(27)}$.

The use of validated tools in a topic that is so relevant and specific to the PHC scenario is of great importance to broaden and qualify the knowledge produced in this context. To this end, the availability of validated tools for this purpose is essential. The studies of tool construction and validation are important, since, when validated, they give scientific character to the tools ${ }^{(28)}$.

\section{Study limitations}

It is known that content validation is an important step in the development of new measurement tools; however, it is recognized the need for additional psychometric measures, such as new studies that assess the applicability of the same.

\section{Contributions to the sectors of Nursing, Health or Public Policy}

In Brazil, to date, there are no large scale studies aimed at instituting and analyzing strategies that aim to increase adherence to $\mathrm{PHC}$ precautionary practices. The current studies have been applied individually in hospital units. 
The production of this tool is considered a great advance in the area of knowledge, since there is not a validated material available similar, specific, for the PHC. This adds the points considered critical by professionals, which confers an identity with the reality experienced by the authors and literature, empowering the tool.

\section{CONCLUSION}

It is concluded that the proposed tool, considering the axes: risk identification; hands hygiene; use of common glove; use of mask and cough etiquette and safe medication and sharps disposal for assessment of professional knowledge and behavior regarding adherence to precautions has been validated by judges and is available for use at PHC.

\section{FUNDING}

This research is part of the project "Desenvolvimento de estratégia educativa em precauções para a transmissão de microrganismos na atenção primária em saúde e hospitalar" (Development of educational strategy in precautions for the transmission of microorganisms in Primary Health Care and hospital), in the form Regular Support to Research, of the Foundation of Support to Research of the State of São Paulo (FAPESP), FAPESP process 2014/08663-1.

\section{REFERENCES}

1. Padoveze $M C$, Fortaleza $\mathrm{CMCB}$. Infecções relacionadas à assistência à saúde: desafios para a saúde pública no Brasil. Rev Saúde Públ [Internet]. 2014 [cited 2017 Jun 23];48(6):995-1001. Available from: http://www.scielo.br/pdf/rsp/v48n6/pt_0034-8910rsp-48-6-0995.pdf

2. Nogueira Jr C, Mello DS, Padoveze MC, Boszczowski I, Levin AS, Lacerda RA. Characterization of epidemiological surveillance systems for healthcare-associated infections (HAI) in the world and challenges for Brazil. Cad Saúde Pública [Internet]. 2014 [cited 2017 Jun 23];30(1):11-20. Available from: http://www.scielo.br/pdf/csp/v30n1/0102-311X-csp-30-01-00011.pdf

3. US. Centers for Disease Control and Prevention - CDC. Guide to infection prevention in outpatient settings: minimum expectations for safe care. Version 2.3 [Internet]. Atlanta; 2016 [cited 2017 Jun 23]. Available from: https://www.cdc.gov/infectioncontrol/pdf/ outpatient/guide.pdf

4. Bottaro BB, Pereira FMV, Reinato LAF, Canini SRMS, Malaguti-Toffano SE, Gir E. Adherence to standard precautions by nursing professionals: a literature review. Rev Enferm UFPE [Internet]. 2016 [cited 2017 Jun 23];10(3):1137-42. Available from: http://www. revista.ufpe.br/revistaenfermagem/index.php/revista/article/view/7380/pdf 9898

5. Padoveze MC, Figueiredo, RM. The role of primary care in the prevention and control of healthcare associated infections. Rev Esc Enferm USP [Internet]. 2014 [cited 2017 Jun 23];48(6):1132-8. Available from: http://www.scielo.br/pdf/reeusp/v48n6/00806234-reeusp-48-06-1137.pdf

6. Pereira FMV, Lam SC, Chan JHM, Malaguti-Toffano SE, Gir E. Difference in compliance with Standard Precautions by nursing staff in Brazil versus Hong Kong. Am J Infect Control [Internet]. 2015 [cited 2017 Jun 23]15:1-4. Available from: http://www.ajicjournal. org/article/S0196-6553(15)00191-1/pdf

7. Martins RJ, Moimaz SAS, Sundefeld MLMM, Garbin AJI, Gonçalves PRV, Garbin CAS. Adesão às precauções padrão sob o prisma do Modelo de Crenças em Saúde: a prática de reencapar agulhas. Ciênc Saúde Colet[Internet]. 2015[cited 2017 Jun 23];20(1):1938. Available from: http://www.scielo.br/pdf/csc/v20n1/pt_1413-8123-csc-20-01-00193.pdf

8. Giard M, Laprugne-Garcia E, Caillat-Vallet E, Russel I, Verjat-Trannoy D, Ertzscheid MA, et al. Compliance with standard precautions: results of a French national audit. Am J Infect Control [Internet]. 2016[cited 2017 Jun 23];44:8-13. Available from: https://www. ncbi.nlm.nih.gov/pubmed/26341402

9. Powers D, Armellino D, Dolansky M, Fitspatrick J. Factors influencing nurse compliance with Standard Precautions. Am J Infect Control[Internet]. 2016[cited 2017 Jun 23];44(1):4-7. Available from: http://www.ajicjournal.org/article/S0196-6553(15)01035-4/pdf

10. Oliveira $\mathrm{AC}$, Paula $\mathrm{AO}$. Fatores relacionados à baixa adesão à higienização das mãos na área da saúde: uma reflexão. Cienc Cuid Saude [Internet]. 2014[cited 2017 Jun 23];13(1):185-89. Available from: http://www.periodicos.uem.br/ojs/index.php/ CiencCuidSaude/article/view/13410

11. Santos TCR, Roseira CE, Piai-Morais TH, Figueiredo RM. Hand hygiene in hospital environments: use of conformity indicators. Rev Gaúcha Enferm[Internet]. 2014[cited 2017 Jun 23];35(1):70-7. Available from: http://www.scielo.br/pdf/rgenf/v35n1/19831447-rgenf-35-01-00070.pdf

12. Maroldi MAC, Felix AMS, Dias AAL, Kawagoe JY, Padoveze MC, Ferreira SA, et al. Adherence to precautions for preventing the transmission of microorganisms in primary health care: a qualitative study. BMC Nursing (Online) [Internet]. 2017 [cited 2017 Nov 14]; 16:49-eletrônico. Available from: https://www.ncbi.nlm.nih.gov/pmc/articles/PMC5594588/pdf/12912_2017_Article_245.pdf

13. Martin-Madrazo C, Soto-Diaz S, Canada-Dorado A, Salinero-Fort MA, Medina-Fernandez M, Carrilo de Santa-Pau E, et al. Cluster randomized trial to evaluate the effect of a multimodal hand hygiene improvement strategy in primary care. Infect Control Hosp Epidemiol[Internet]. 2012 [cited 2017 Jun 27];33(7):681-8. Available from: https://www.ncbi.nlm.nih.gov/pubmed/22669229 
14. Mahfouz AA, Abolyazid A, Al-Musa HM, Awadallah NJ, Faraheen A, Khalil S, et al. Hand hygiene knowledge of primary health care workers in Abha city, South Western Saudi Arabia. J Fam Med Primary Care [Internet]. 2017 [cited 2017 Jun 23];6(1):136-40. Available from: https://www.ncbi.nlm.nih.gov/pmc/articles/PMC5629878/

15. Rezende KCAD, Tipple AFV, Souza ACS, Siqueira KM, Alves SB, Salgado TA, et al. Risco de exposição a material biológico em unidades de saúde da atenção primária à saúde. Rev Enferm UERJ [Internet]. 2016 [cited 2017 Jun 23];24(2):e6442. Available from: http://www.e-publicacoes.uerj.br/index.php/enfermagemuerj/article/view/6442/18690

16. Pérez-Pérez P, Herrera-Usagre M, Bueno-Cavanillas A, Alonso-Humada MS, Buiza-Camacho B, Vásquez-Vásquez M. Higiene de las manos: conocimientos de los profesionales y áreas de mejora. Cad Saúde Publica[Internet]. 2015[cited 2017 Jun 23];31(1):14960. Available from: http://www.scielo.br/pdf/csp/v31n1/0102-311X-csp-31-01-00149.pdf

17. Alfahan A, Alhabib S, Abdulmajeed I, Rahman S, Bamuhair S. In the era of corona virus: health care professionals' knowledge, attitudes, and practice of hand hygiene in Saudi primary care centers: a cross-sectional study. J Commun Hosp Internal Med Perspect[Internet]. 2016 [cited 2017 Jun 23]:6(4):10.3402/jchimp.v6.32151. Available from: https://www.ncbi.nlm.nih.gov/pmc/ articles/PMC5016750/

18. Bedoya G, Dolinger A, Rogo K, Bedoya G, Dolinger A, Rogo K, Mwaura N, Wafula F, Coarasa J, et al. Observations of infection prevention and control practices in primary health care, Kenya. Bull WHO[Internet]. 2017 [cited 2018 Jan 05];95(7):503-16. Available from: https://www.ncbi.nlm.nih.gov/pmc/articles/PMC5487970/

19. Polit DF, Beck CT. Fundamentos de pesquisa em enfermagem: avaliação de evidências para a prática da enfermagem. 7 ed. Porto Alegre: Artmed; 2011.

20. Coluci MZO, Alexandre NMC, Milani D. Construção de instrumentos de medida na área de saúde. Ciênc Saúde Colet[Internet]. 2015 [cited 2017 Jun 23];20(3):925-36. Available from: http://www.scielo.br/pdf/csc/v20n3/1413-8123-csc-20-03-00925.pdf

21. Organização Mundial da Saúde - OMS. Salve Vidas: Higienize suas Mãos. Higiene das Mãos na Assistência à Saúde Extrahospitalar e Domiciliar e nas Instituições de Longa Permanência - Um Guia para a Implementação da Estratégia Multimodal da OMS para a Melhoria da Higiene das Mãos e da Abordagem "Meus 5 Momentos para a Higiene das Mãos" [Internet]. Brasília; 2014[cited 2017 Jun 23]. Available from: http://www20.anvisa.gov.br/segurancadopaciente/index.php/publicacoes/item/ assistencia-a-saude-extra-hospitalar-e-domiciliar-e-nas-instituicoes-de-longa-permanencia

22. Felix AMS, Vitor E, Malaguti SET, Gir E. Individual, work-related and institutional factors associated with adherence to standard precautions. J Infect Control [Internet]. 2013 [cited 2017 Jun 23];2(2):106-11. Available from: http://jic.abih.net.br/index.php/jic/ article/viewFile/34/pdf_1

23. Quan M, Wang X, Wu H, Yuan X, Lei D, Jiang Z, et al. Influencing factors on use of standard precautions against occupational exposures to blood and body fluids among nurses in China. Int J Clin Exp Med [Internet]. 2016[cited 2017 Jun 23];8(12):22450459. Available from: http://www.ncbi.nlm.nih.gov/pmc/articles/PMC4730013/

24. Locks L, Lacerda JT, Gomes E, Serratine ACP. Qualidade da higienização das mãos de profissionais atuantes em unidades básicas de saúde. Rev Gaúcha Enferm[Internet]. 2011 [cited 2017 Jun 23];32(3):569-75. Available from: http://www.scielo.br/pdf/rgenf/ v32n3/19.pdf

25. Figueiredo RM, Maroldi MAC. Home care: health professionals at risk for biological exposure. Rev Esc Enferm USP[Internet]. 2012[cited 2017 Jun 23];46(1):145-50. Available from: http://www.scielo.br/pdf/reeusp/v46n1/en_v46n1a20.pdf

26. Eqwuenu SE, Okanlawon FA. Infection control: nurses' knowledge and practice of universal precaution in Delta State, Nigeria. Afr J Med Sci[Internet]. 2014 [cited 2017 Jun 01];43(3):127-34. Available from: https://www.ncbi.nlm.nih.gov/pubmed/25474987

27. Santos TCR, Roseira CE, Passos IPBD, Figueiredo RM. The use of gloves by nursing staff: transmission risk protection. J Nurs UFPE[Internet]. 2013[cited 2017 May 18];7(11):6438-45. Available from: http://www.revista.ufpe.br/revistaenfermagem/index. php/revista/article/viewArticle/4343

28. Oliveira SKP, Lima FET. Content validation of the self-care assessment scale for health failure patients. Rev Rene[Internet]. 2017 [cited 2017 May 18];18(2):148-55. Available from: http://www.revistarene.ufc.br/revista/index.php/revista/article/view/2680 